Brookes, A. J. (195I). F. Frms' Cl., Lond., p. 64.

Callow, E. M. (1944). F. agric. Sci. 34, 177 .

Cooper, M. M. (1953). Beef Production. Edinburgh: Thomas Nelson and Sons.

Director-General of Agriculture. (1953). Rep. Dep. Agric. N.Z.

Evans, G. L. B. (1949). Proc. Brit. Soc. Anim. Prod. I Ith Mtg, p. 34.

Godden, W. (1948). Agric. Progr. 23, 105.

Hamilton, R. A. (1952). F. Frms' Cl., Lond., p. 53.

Hughes, G. P. (1954). Personal communication.

Knapp, B. \& Clark, R. T. (1950). F. Anim. Sci. 9, 582.

McMeekan, C. P. (1941). F. agric. Sci. 31, I.

Shaw, T. (I949). Proc. Brit. Soc. Anim. Prod. I Ith Mtg, p. 7.

Wallace, L. R. (1953). Proc. N.Z. Soc. Anim. Prod. 13, 5.

Wood, T. B. \& Newman, L. F. (I928). Beef Production in Great Britain. Liverpool: Silcocks.

\title{
Factors Influencing the Efficiency of Feed Conversion by Sheep
}

\section{By L. R. Wallace, Ruakura Animal Research Station, Department of Agriculture, New Zealand}

Although, to-day, we are not supposed to be comparing the efficiencies with which the various classes of farm livestock convert animal feedstuffs to human food, it is worth recalling that dairy cattle are much more efficient in this connexion than are the larger meat-producing animals (Brody, I945; Leitch \& Godden, 1953). Now dairy cattle, beef cattle and sheep do not differ greatly in their digestive capacities, and it is instructive to inquire briefly into the origin of the very considerable difference in their efficiencies as food producers.

\section{Relative efficiency of milk and meat}

When the dairy cow producing milk is compared on an annual basis with the breeding ewe producing meat in the form of lamb, there are several important considerations to be noted. First, whereas the cow is normally milking for approximately Io months of the $\mathrm{I} 2$, the ewe is quite unproductive for more than half the time-her lactation period being usually only about 4 months. Furthermore, with the cow the milk produced is the measured end-product, the whole of which is consumed directly by man: the ewe's milk, however, is merely part of the raw material which has still to be converted to human food by the lamb, which again stores some of the energy in organs that are not eaten. Thus, production of fat lamb is relatively inefficient, firstly on account of the high overhead costs of milk production by the ewe, secondly on account of the high losses involved in the double conversion of part of the feedstuffs first to milk and then to meat, and lastly because the lamb itself is not completely edible. Against the comparatively small amount of product represented by the fat lamb carcass must be charged not only the feed consumed by the lamb itself but also the ewe's requirements over the whole year. 


\section{The feed costs of the lamb}

There are two major considerations affecting the amount of feed-other than milk-consumed directly by a lamb per lb. live weight produced. The first is its rate of growth. Naturally the faster a lamb grows the less time it takes to reach slaughter weight, and therefore the greater the saving in the costs of body maintenance. The second is the weight to which the lamb is carried before slaughter. As the lamb grows, the weight gains become progressively more expensive. One reason for this change depends on our method of reckoning, for until it is a month old the lamb lives almost wholely upon its mother's milk-which in the present calculation is not charged against it-whereas after that age plant feedstuffs form an everincreasing part, and finally the whole, of its diet. Also, owing to the differential nature of the lamb's growth, the energy content of the live-weight gains made increases progressively. At birth the lamb carcass consists almost entirely of bone and muscle, and in the early stages of growth weight gains largely represent increases in these tissues (Table I). Later, adipose tissue is laid down, and chemical fat is deposited in it in ever increasing quantities, so that at the heavier weights not

\section{Table I. Composition of carcasses of Suffolk lambs (Wallace, unpublished)}

\begin{tabular}{cccccc} 
Carcass weight & \multicolumn{7}{c}{ Tissue in carcass } & Muscle & Fat & Calories in carcass & Protein in carcass \\
(lb.) & $(\%)$ & $(\%)$ & $(\%)$ & $\left(\right.$ Cal. $\left.\times 10^{3}\right)$ & $(1 \mathrm{~b})$. \\
10 & 25.1 & 62.2 & 12.7 & 6.4 & 1.47 \\
20 & 19.5 & 62.1 & 18.4 & 17.5 & 2.76 \\
30 & 16.0 & 60.9 & 23.1 & 32 & 3.92 \\
40 & 13.8 & 57.4 & 28.8 & 52 & 4.86 \\
50 & 12.5 & 54.4 & 32.9 & 73 & 5.76 \\
60 & 11.7 & 51.8 & 36.5 & 97 & 6.58 \\
70 & 11.0 & 48.9 & 40.1 & 124 & 7.27 \\
80 & 10.4 & 45.7 & 43.9 & 154 & 7.84
\end{tabular}

only do deposits of fatty tissue form a progressively higher percentage of the carcass, but the percentage of chemical fat in this tissue becomes ever greater.

Some years ago, while at the School of Agriculture in Cambridge, I carried out experiments in which lambs were grown at widely differing rates and their feed consumption and that of their mothers were separately recorded (Wallace, 1948). Data from some of these records are given in Table 2, and these illustrate how the cost of each pound of live weight, in terms of feeding-stuffs eaten directly by the lamb, depends upon growth rate, and is higher for each stage of increasing weight and age.

The level of the ewe's milk yield is a matter of great importance in relation to the efficiency of feed conversion by the lamb, because the amount available to the lamb in the first 4 weeks of life largely determines its growth rate. For example, with Border Leicester-Cheviot $\times$ Suffolk lambs I (Wallace, I948) found that each additional $4 \mathrm{lb}$. of milk consumed during the Ist month after birth led to an additional pound of live weight at 4 weeks of age; and a number of others have 
Table 2. Feed consumption* of lambs/lb. live weight in relation to growth rate and live weight, from data of Wallace (1948)

\begin{tabular}{|c|c|c|c|c|c|c|c|c|}
\hline \multirow[b]{2}{*}{ Live weight (lb.) } & \multicolumn{4}{|c|}{ Age (weeks) } & \multicolumn{4}{|c|}{$\begin{array}{l}\text { Gross digestible energy } \dagger \text { consumed } \\
\text { (lb./lb. live weight) }\end{array}$} \\
\hline & $\underset{A}{\operatorname{Lamb}}$ & $\underset{B}{\operatorname{Lamb}}$ & $\underset{\mathrm{C}}{\mathrm{Lamb}}$ & $\underset{\mathrm{D}}{\operatorname{Lamb}}$ & $\underset{\mathrm{A}}{\mathrm{Lamb}}$ & $\underset{\text { B }}{\text { Lamb }}$ & $\begin{array}{c}\text { Lamb } \\
\mathrm{C}\end{array}$ & $\underset{D}{\operatorname{Lamb}}$ \\
\hline 50 & $4 \cdot 0$ & $7 \cdot 5$ & $9 \cdot 5$ & II.O & 0.1 & 0.2 & 0.5 & 0.7 \\
\hline 80 & 10.5 & $13 \cdot 0$ & $16 \cdot 0$ & $20 \cdot 0$ & 0.5 & 0.7 & $1 \cdot 3$ & 1.6 \\
\hline 110 & 15.5 & 20.5 & $28 \cdot 5$ & $38 \cdot 0$ & $I \cdot I$ & $1 \cdot 5$ & 2.6 & $3 \cdot 5$ \\
\hline 140 & 24.0 & 32.0 & 40.0 & $50 \cdot 0$ & $2 \cdot I$ & $2 \cdot 6$ & $3 \cdot 4$ & $4 \cdot 1$ \\
\hline
\end{tabular}

found high correlations between the milk yields of ewes and the weight gains of their lambs (Bonsma, 1939; Barnicoat, Logan \& Grant, I949; Thomson \& Thomson, I953).

A high rate of gain during early life is desirable not only in itself, but because it affects the age at which the lamb is able to consume large quantities of plant feedstuffs.

In fat-lamb flocks a high level of milk yield is essential if lambs are to be obtained fat off their mothers at an early age, for this can only be achieved if growth is rapid and uninterrupted from birth onwards (Pálsson \& Vergés, 1952), and in the production of store lambs good milk yield is essential for reasonable growth on account of the poor quality of the other feedstuffs available to the lamb. In both types of flock the milking ability of the ewes is of special importance where there are many twins. Hammond (1932) demonstrated many years ago that lambs born as twins but reared as singles grow better than those reared as twins, and it is undoubtedly true of all breeds that milk yield becomes a factor limiting growth when it has to be shared between two or more lambs.

\section{The feed costs of the ewe}

Clearly the feed costs of the ewe per $\mathrm{lb}$. lamb produced can only be lowered by reducing the total amount of feed eaten or by increasing the amount of lamb produced. We shall see later that quite a lot may be done to prevent wastefully high feed intake by the ewe. As to the amount of lamb, the main considerations are the number reared and the weight of meat yielded by each, which depends upon the weight at slaughter.

There are three possible ways whereby the number of lambs may be increased: firstly, by increasing the number reared at each lambing, secondly, by increasing the number of lambings each year, and thirdly by increasing the average length of the breeding life of the ewe.

Number of lambs reared at each lambing. The number is largely determined by the breed and strain of ewe employed, for some breeds such as the Suffolk and the Border Leicester $\times$ Cheviot are renowned for their high fertility-others such 
as the Romney and Welsh Mountain are by nature less prolific. But lambing percentages are dependent also upon environmental factors--particularly upon the level of nutrition of the ewe at the time of mating and during late pregnancy and early lactation.

Number of lamb crops per year. Sheep are like cows in that they normally produce only one crop of offspring each year. However, in the ewe, gestation is short enough to leave time within the year for a second pregnancy and a second crop of lambs. Although most breeds of sheep will not accept service during the spring and summer months, they can now be made to do so by appropriate hormone treatment, and there may be a place for this procedure in certain types of farming practice.

Length of breeding life. The feed cost of rearing female stock for breeding is one of the important overhead charges in meat production. Normally ewe lambs are not bred until 18 months old, producing their first lambs at 2 years of age. However, spring-born lambs that have been really well grown from birth can be bred in their first autumn and experience no special difficulty in rearing their lambs quite successfully. Extension of the other end of the ewe's breeding career is of equal or even greater importance since fertility tends to increase with age, reaching a maximum about the 6 th or 7 th year. Unfortunately many breeding ewes never survive to this age, and many that do have to be culled on account of failing dentition.

Stage of slaughter. The way the amount of feed consumed by the ewe per lb. lamb declines as the lamb's weight increases is illustrated in Table 3 , which gives figures based upon the results obtained for two typical ewes of my individual feeding experiments previously referred to. The decline is steep at first, but becomes progressively less so as the lamb grows heavier.

Table 3. Annual feed requirements of ewes and lambs for production of live weight, carcass weight, protein and calories, based on data of Wallace (1948)

\begin{tabular}{|c|c|c|c|c|c|c|c|c|c|}
\hline \multirow[b]{3}{*}{$\begin{array}{c}\text { Age of } \\
\text { lamb } \\
\text { (weeks) }\end{array}$} & \multirow[b]{3}{*}{$\begin{array}{l}\text { Weight } \\
\text { of lamb } \\
\text { (lb.) }\end{array}$} & \multicolumn{8}{|c|}{ Feed consumption (lb. T.D.N.) } \\
\hline & & \multicolumn{2}{|c|}{ Ewe } & \multicolumn{2}{|c|}{ Lamb } & \multicolumn{4}{|c|}{ Ewe and lamb } \\
\hline & & Total & $\begin{array}{l}\text { /lb, live } \\
\text { weight of } \\
\text { lamb }\end{array}$ & Total & $\begin{array}{l}\text { /lb. live } \\
\text { weight of } \\
\text { lamb }\end{array}$ & $\begin{array}{l}\text { llb. live } \\
\text { weight of } \\
\text { lamb }\end{array}$ & $\begin{array}{l}\text { /lb. carcass } \\
\text { weight of } \\
\text { lamb }\end{array}$ & $\begin{array}{l}/ 1 \mathrm{~b} . \\
\text { protein in } \\
\text { lamb }\end{array}$ & $\begin{array}{l}/ 1000 \\
\text { Cal. in } \\
\text { lamb }\end{array}$ \\
\hline $\begin{array}{l}10 \\
13 \\
16 \\
24 \\
32\end{array}$ & $\begin{array}{r}77 \\
97 \\
\text { I I } \\
132 \\
\text { I41 }\end{array}$ & $\begin{array}{l}663 \\
688 \\
721 \\
721 \\
721\end{array}$ & $\begin{array}{l}8 \cdot 6 \\
7 \cdot 0 \\
6 \cdot 4 \\
5 \cdot 4 \\
5 \cdot 1\end{array}$ & $\begin{array}{l}\text { Ewes } \\
31 \\
75 \\
134 \\
260 \\
314\end{array}$ & $\begin{array}{c}\text { single lan } \\
0 \cdot 4 \\
0 \cdot 8 \\
1 \cdot 2 \\
2 \cdot 0 \\
2 \cdot 2\end{array}$ & $\begin{array}{l}9 \cdot 0 \\
7 \cdot 8 \\
7 \cdot 6 \\
7 \cdot 4 \\
7 \cdot 3\end{array}$ & $\begin{array}{l}18.5 \\
15.6 \\
14.9 \\
14.1 \\
13.8\end{array}$ & $\begin{array}{l}\text { I49 } \\
\text { I34 } \\
\text { I34 } \\
\text { I35 } \\
\text { I37 }\end{array}$ & $\begin{array}{r}\text { I4.8 } \\
\text { I0.7 } \\
9.4 \\
8 \cdot 0 \\
7.5\end{array}$ \\
\hline \multicolumn{10}{|c|}{$\begin{array}{cc}\text { Ewes } & \text { with twin lambs } \\
61 & 0.5 \\
144 & 0.9 \\
237 & 1 \cdot 2 \\
493 & 2 \cdot 0 \\
755 & 2.7\end{array}$} \\
\hline
\end{tabular}

The feed costs of the ewe and lamb together

We have already seen that, in contrast to those of the ewe, the feed costs of the lamb itself increase as it grows older, so that from the point of view of the overall efficiency of conversion of the total feed eaten by the ewe and lamb together, there 
is clearly an optimum stage of slaughter which will be reached when the rate at which the ewe's overheads decline falls below that at which the lamb's costs increase.

Owing to the differential nature of growth this optimum stage of slaughter is likely to be different for different breeds and according to whether we are considering the efficiency of production of live weight, or carcass meat, or of calories or protein. The point of optimum efficiency is also likely to be different as between ewes according to the number of lambs reared and their rate of growth.

It appears (Table 3 ) that the optimum slaughter weight is less for protein than for carcass meat or calories, and in general less for each of these with twins than with single lambs. The figures make it clear that for maximum efficiency of food conversion in the production of carcass meat it is desirable to carry the lambs to fairly heavy weights before slaughter.

Since the maintenance requirement of a small ewe is less than that of a large one, a practice that should make for overall efficiency is to keep ewes of a small breed and mate these to heavier types of ram, provided the milk-productive capacity of the ewe is sufficiently good to allow the lamb to make rapid growth. The cross between the Welsh Mountain ewe and the Suffolk ram is a good example of the successful application of this method in commercial practice.

Turning now to the practical question of how the ewe flock should be managed and fed throughout the year to obtain maximum efficiency of feed conversion, it should be emphasized that there are some periods when it is of critical importance that a high level of nutrition be provided, and others when much lower levels are permissible and even desirable. The ewes should be flushed, i.e. provided with an improved, high level of feeding shortly before and during mating, to ensure a high ovulation rate and lambing percentage. Working with Romney ewes in New Zealand, I found that different levels of feeding imposed over a period as short as 3 weeks before the rams were put out led to a large difference in the percentage of lambs born to mated ewes. During the early part of pregnancy, however, the ewes can be restricted to a bare maintenance level of feeding without disadvantage, for there is no evidence that this restriction increases embryonic failure, or impairs subsequent lactation performance. During late pregnancy the position is more debatable. It has been thoroughly established that the plane of nutrition during this time can have a marked effect on the birth weight of the lambs, particularly the twins, and that at very low levels of feeding, ewe and lamb losses are increased (Wallace, I948; Thomson \& Thomson, I948-9). However, Coop (1950) in extensive field experiments with a total of $175^{\circ}$ ewes over three seasons, found lamb losses just as great in flocks fed well before lambing as in those kept on a fairly low plane of nutrition. My recent work suggests that an intermediate moderate level of feeding is preferable from the point of view of lamb losses to either a very high or very low one. Nutrition during late pregnancy is also of some importance in relation to milk production, but it is even more essential to feed the ewes well during lactation itself if they are to give good milk yields (Barnicoat et al. 1949). So long as the ewes and lambs are grazing together a high level of feeding must be provided, but once the lambs are weaned they should be 
given preferential treatment, whereas the ewes may be reduced to a bare maintenance level until the approach of the next mating season. This arrangement not only saves feed, but also brings the ewes into that hard store condition thought to lead to good breeding performance.

\section{General considerations}

So far we have considered the efficiency of the ewe and her lamb as a unit in converting feeding-stuffs to meat. There remain to be considered those other factors that affect the efficiency of the sheep industry as a whole.

Efficient utilization of the nation's feedstuffs implies that they be used as far as possible for the purpose to which they are best suited. Thus high-quality feedstuffs, capable of fattening animals, should not be used for overwintering store animals or rearing replacements; hence the importance of stratification within the sheep industry. Areas where, owing to difficulties of contour or unfavourable climate conditions, it is impossible to provide the uniformly high level of nutrition required for the rapid and uninterrupted growth and efficient fattening of animals can nevertheless be a tremendous national asset if stocked with breeding animals and used to produce store lambs and breeding replacements for the naturally more favoured fattening country.

Obviously there is little point in striving for efficient feed conversion within the animal if the feedstuffs themselves have been expensively purchased or wastefully produced. At a time when meat is to be rationed by price it is essential that it be produced as cheaply as possible. This surely implies concentration upon a grassland farming system in which close attention is paid to enlightened pasture management in order to ensure that large quantities of feed are grown and as high a proportion as possible actually consumed. Moreover it is obviously important that there be close correspondence between the seasonal requirements of the animals and the seasonal growth of the grass. As large a proportion as possible of the pasture should be grazed directly by the animal, for all forms of fodder conservation involve not only added financial costs but considerable losses in feed value.

Full utilization of cheap summer grazing may well produce a glut of meat in the autumn. It could be dealt with by the provision of adequate refrigerated storage space. Alternatively farmers could be encouraged to aim for high lambing percentages and to fatten a large proportion of lambs off their mothers in the early summer; later-born and slower-growing lambs could be fattened out in the late autumn.

The fact that feed conversion to carcass meat tends to become more efficient as the slaughter weight is raised has been mentioned. In practice there is a limit beyond which the weight cannot be increased without adversely affecting the quality of the meat. High-quality meat is that for which the consumer is prepared to pay a high price and its value is dependent upon the size and shape of the various joints and their proportions in terms of bone, muscle and fatty tissues. During the earlier part of its growth, increase in the carcass weight of a lamb is accompanied by increase in quality, as the more costly joints-the loin and legs-grow relatively 
larger, and the proportion of muscle and fat to bone rises. After the optimum point is reached, however, excessive fat is laid down and value falls rapidly. The weight at which this optimum quality is reached depends largely on the breed (Hammond \& Murray, 1934; Hirzel, 1939). Lambs of early-maturing breeds such as the Southdown are of highest quality at light weights and soon become over-fat, whereas larger breeds such as the Suffolk do not reach their optimum until much higher weights. For mutton and lamb too, far more than for beef, the actual weight of the carcass as well as its shape and composition, affects the price per $l b$., for the consumer tends to prefer the required weight of meat to be in the form of a whole joint such as a leg or shoulder, which must, therefore, be of a size adapted to the size of the household. Before the war, the general trend of demand was for small compact joints with a high proportion of lean meat and only enough fat to prevent drying out in cooking. The end of rationing is too recent for one to be certain, but it seems likely that on the free market this type of meat will again command the highest price.

In this paper it has been possible to mention only the major factors that bear directly upon the efficiency of food conversion in the sheep industry. One could elaborate almost indefinitely, but I shall have achieved all I hoped to do if I have succeeded in presenting a broad view of the problem as a whole which will help to make clear the relevance of the many other considerations that have not been mentioned, but which influence overall efficiency by their bearing upon the health of the animals, their reproductive ability, wastage rates and so on.

\section{REFERENCES}

Barnicoat, C. R., Logan, A. G. \& Grant, A. I. (1949). 7. agric. Sci. 39, 44.

Bonsma, F. N. (1939). Publ. Univ. Pretoria Agric. no. 48.

Brody, S. (1945). Bioenergetics and Growth. New York: Reinhold Publishing Corp.

Coop, I. E. (1950). Y. agric. Sci. 40, 3 I I.

Hammond, J. (1932). Growth and Development of Mutton Qualities in the Sheep. Edinburgh: Oliver and Boyd.

Hammond, J. \& Murray, G. N. (1934). F. agric. Sci. 24, 233.

Hirzel, R. (1939). Onderstepoort $\mathcal{Y}$. vet. Sci. 12, 379.

Leitch, I. \& Godden, W. (1953). Tech. Commun. Bur. Anim. Nutr., Aberd., no. 44.

Pálsson, H. \& Vergés, J. B. (1952). J. agric. Sci. 42, 93.

Thomson, A. M. \& Thomson, W. (1948-9). Brit. F. Nutr. 2, 290.

Thomson, W. \& Thomson, A. M. (1953). Brit. F. Nutr. 7, 263.

Wallace, L. R. (1948). 7 . agric. Sci. 38, 93. 